HEALTHY MINDS IN HEALTHY BODIES.

AN INTERNATIONAL COMPARISON OF EDUCATION-RELATED INEQUALITY IN PHYSICAL

HEALTH AMONG OLDER ADULTS

Hendrik Jürges

141-2007

๑ $\boldsymbol{m e a - M a n n h e i m ~ R e s e a r c h ~ I n s t i t u t e ~ f o r ~ t h e ~ E c o n o m i c s ~ o f ~ A g i n g ~}$

L13, 17_D-68131 Mannheim_Phone +49 621 181-2773/1862_Fax +49 621 181-1863_www.mea.uni-mannheim.de 


\title{
Healthy minds in healthy bodies. An international comparison of education-related inequality in physical health among older adults
}

\author{
Hendrik Jürges \\ MEA, University of Mannheim \\ L13,17 \\ 68131 Mannheim \\ Germany \\ Tel +49-621-181-3519 \\ Fax +49-621-181-1863 \\ Email: juerges@mea.uni-mannheim.de
}

Juni 2007

\begin{abstract}
Education is arguably the most important correlate of health We study educationrelated inequality in the physical of older adults across 11 European countries and the US. Combining data from HRS 2002, ELSA 2002 and SHARE 2004, our results suggest that education is strongly correlated with health both across and within countries. Educationrelated inequality in health is larger in Mediterranean and Anglo-Saxon countries than in western European countries. We find no evidence of a trade-off between health levels and equity in health. Education-related inequality in health hardly driven by income or wealth effects (except in the US), and differences in health behaviors (smoking) by education level contribute surprisingly little health differences across education groups.
\end{abstract}

Keywords: Socioeconomic inequality in health, concentration index, cross-country analysis, decomposition

JEL-Codes: I12, I21, J14

Acknowledgements: This paper uses data from the early release 1 of SHARE 2004. This release is preliminary and may contain errors that will be corrected in later releases. The SHARE data collection has been primarily funded by the European Commission through the 5th framework programme (project QLK6-CT-2001-00360 in the thematic programme Quality of Life). Additional funding came from the US National Institute on Ageing (U01 AG09740-13S2, P01 AG005842, P01 AG08291, P30 AG12815, Y1-AG-4553-01 and OGHA 04-064). Data collection in Austria (through the Austrian Science Fund, FWF), Belgium (through the Belgian Science Policy Office) and Switzerland (through BBW/OFES/UFES) was nationally funded. 


\section{Introduction}

A strong relationship between socio-economic status and health has been documented in numerous studies: Better educated individuals are healthier than less educated, individuals with high income are healthier than those with low income, employees at the top end of the occupational hierarchy are healthier than those working at the bottom end of the hierarchy, and wealthy individuals are healthier than poor individuals. The relationship is so ubiquitous that is often simply referred to as "the" gradient (Deaton 2003).

In this paper, we aim at contributing to the growing literature on cross-national comparisons of the gradient. Combining data from US Health and Retirement Study (HRS) 2002, the English Longitudinal Study of Ageing (ELSA) 2002 and the Survey of Health, Ageing and Retirement in Europe (SHARE) 2004, this paper compares socio-economic inequality in physical health across 11 European countries and the US. In contrast to the more recent comparative literature on socio-economic inequalities in health (e.g. Van Doorslaer et al. 1997, Van Doorslaer \& Koolman 2004), we study education-related inequalities. We deviate from common practice for several reasons. First, education is arguably the most important correlate of health (conditional on age). The partial effects of income and occupation are often found to be much weaker than those of education (Grossman \& Kaestner 1997, Grossman 2005). Hence, we expect education-related inequalities in health to be larger than incomerelated inequalities. Second, theoretically, the economic literature has identified causal effects of education on health through at least three plausible channels: (a) education raises efficiency in health production (raises the marginal productivity of inputs), i.e. it increases an individuals productive efficiency. (b) education changes inputs into health production (through information) and thereby increases allocative efficiency. (c) education itself changes time preference (and thus inputs into health production) because schooling focuses students' attention on the future (Becker \& Mulligan 1997). Third, among the components of socioeconomic status (education, income, and occupation), education seems to be the one that - in the long run - is most amenable to public policy interventions. The correlation between income (or wealth) and health seems to suggests that income redistribution is a key measure to decrease health inequalities. But, as noted by Deaton (2002), it is important to frame policy in terms of health and wealth simultaneously. Improving one at the expense of the other involves a difficult and probably unnecessary trade-off. One possible policy instrument for simultaneously improving health and wealth is education. If education improves both wealth 
and health simultaneously, giving people access to more and better education will be more successful than redistributing income or expanding public health care expenditures.

A causal analysis of the effects of education health is beyond the scope of the present paper (recent papers that address this issue are Adams (2002), Arendt (2005) or Lleras-Muney (2005)). We rather aim at complementing the recent literature on socio-economic inequalities in health by combining a new European data set with comparable US data. We thus broaden the geographic and institutional scope of the analysis by including the US as an important comparison country. Due to the nature of the data, we have restricted the analyses of health inequalities to individuals aged 55 and over. Still, our study has several advantages compared to earlier cross-national studies on socio-economic inequalities in health. First, the data sets used combine detailed data on health with detailed data on socio-economic variables like income and wealth. Due to the lack of data, earlier studies have mostly used self-rated health or cardinalisations thereof as the health outcome variable (e.g. Van Doorslaer \& Koolman 2004). However, as shown in Jürges (2007a), self-rated health is not generally comparable across countries, even if exactly the same wording (albeit translated to the local languages) is used. Self-rated health might not even be comparable across different socio-economic groups within countries (Van Doorslaer \& Gerdtham 2003, Etilé \& Milcent 2006, Jürges 2007b). We use a health (utility) index as main health variable that combines detailed objective and subjective aspects of physical health.

The paper is organised as follows: In Section 2, we describe our approach to measuring education-related health inequalities. Section 3 describes the data sets used and the construction of the key variables education and health. In Section 4 we discuss the results. A summary of the main findings is presented in Section 5.

\section{Measuring and decomposing health inequalities}

We use the concentration index as the main measure of education-related health inequality. The methodology - described in this section - closely follows the recent literature, e.g. Wagstaff et al. (2003) and Van Doorslaer and Koolman (2004). Let $y_{i}$ be a continuous measure of health and $R_{i}$ the fractional education rank of individual $i$, then the concentration index $C$ is defined as 


$$
C=\frac{2}{\bar{y}} \operatorname{Cov}\left(y_{i}, R_{i}\right)
$$

$C$ can take on values between -1 and +1 , depending on whether inequalities favour the better or the less educated. The concentration index is closely related to the Gini coefficient, which can be computed in the same way as the concentration index except that rank is not defined in terms of socio-economic characteristics but in terms of health itself. The health concentration index is smaller than the health Gini coefficient except when the health rank and the socioeconomic rank are perfectly correlated.

One attractive feature of the concentration index is that it can be decomposed into parts due to education itself and other correlates of health. The first step is to specify a linear-additive model of health

$$
y_{i}=\alpha+\sum_{k=1}^{K} \beta_{k} x_{k i}+\varepsilon_{i},
$$

where education is among the $x$-variables, say $x_{1}$. Other covariates are, for instance, income, age, sex, or health-related behaviors. Inserting $y_{\mathrm{i}}$ in $C$ and noting that

$$
\operatorname{Cov}\left(x_{k i}, R_{i}\right)=\frac{\bar{x}_{k}}{2} C_{k}
$$

yields

$$
\begin{aligned}
C & =\frac{2}{\bar{y}} \operatorname{Cov}\left(\alpha+\sum_{k} \beta_{k} x_{k i}+\varepsilon_{i}, R_{i}\right) \\
& =\sum_{k} \beta_{k} \frac{\bar{x}_{k}}{\bar{y}} C_{k}+\frac{2}{\bar{y}} \operatorname{Cov}\left(\varepsilon_{i}, R_{i}\right)
\end{aligned}
$$

In words: The concentration index for education-related inequality in health can be decomposed in parts due to education itself, due to variables correlated with education (which shows up in $C_{k}$ ), and a concentration index for $\varepsilon$. The term $\eta_{k} \equiv \beta_{k} \frac{\bar{x}_{k}}{\bar{y}}$ denotes the elasticity of health with respect to $x_{k}$, evaluated at the sample means $\bar{x}_{k}, \bar{y}$. The contribution of variable $k$ to education-related inequality in health equals the health elasticity of $k$ times the educationrelated inequality in variable $k$. Thus, $k$ does only contribute to education-related inequality in health if it has a partial effect on health and if it is unequally distributed across education groups, i.e. correlated with education. In contrast to studies that analyse income-related inequality in health, we use a socio-economic status variable (educational degrees) that enters 
the additive-linear health model as a set of dummy variables. In such a case the residual term $\frac{2}{\bar{y}} \operatorname{Cov}\left(\varepsilon_{i}, R_{i}\right)$ vanishes because $E\left(\varepsilon_{i} \mid R_{i}\right)=E\left(\varepsilon_{i} \mid x_{1 i}\right)=0$. Expression (4) thus simplifies to

$$
C=\sum_{k} \eta_{k} C_{k}
$$

i.e. $C$ can be written as a linear combination of health elasticities and concentration indices. Standard errors for concentration indices are estimated by a bootstrap procedure (with 1000 repetitions), taking account of the inverse sampling probability of each respondent.

\section{Data and Measurement of Key Variables}

The data used in this study are drawn from three large-scale, interdisciplinary surveys on the older population: the 2002 wave of the US Health and Retirement Study (HRS), the 2002 wave of English Longitudinal Study of Ageing (ELSA), and the Survey of Health, Ageing and Retirement in Europe (SHARE) 2004, which currently contains data from 10 different European countries. The three surveys are very similar in their aims and scope. In fact, ELSA and SHARE were modelled closely after the HRS in order to provide researchers with the opportunity to conduct comparative analyses using data on individuals living under different institutional (welfare state) arrangements. HRS, ELSA, and SHARE contain detailed crossnationally comparable data on physical and mental health status, psychological well-being, health care use, health insurance and social security coverage, labour market status and job characteristics, income and wealth, and family support systems of individuals aged 50 and over.

The Health and Retirement Study is a bi-annual panel survey that was started in 1992 and initially covered individuals born between 1931 and 1941. In 1998, the HRS data collection effort was merged with a similar survey that covered the oldest old, born in 1923 or before $($ AHEAD $=$ Asset and Health Dynamics among the Oldest Old). Moreover, new samples comprising the cohorts 1924 to 1930 and 1942 to 1947 were added, such that the HRS covered all individuals born in 1947 or before. For the purpose of our study, we use the 2002 wave extracted from the RAND HRS data file. ${ }^{1}$

\footnotetext{
${ }^{1}$ The RAND HRS Data file is an easy to use longitudinal data set based on the HRS data. It was developed at RAND with funding from the National Institute on Aging and the Social Security Administration. A detailed description of the aims and scope of HRS is given by Juster and Suzman (1995).
} 
The English Longitudinal Study of Ageing was started in 2002, also as a bi-annual panel survey. ${ }^{2}$ The sample was drawn from three survey years of the Health Survey for England (HSE 1998, 1999 and 2001) and covers people aged 50 and over. We use the data collected during the first wave of ELSA, made available through the UK Data Archive, which contain information on about 11,000 respondents. Wales, Scotland, and Northern Ireland, where 16\% of the UK population live, are not part of this survey.

The Survey of Health, Ageing and Retirement in Europe (SHARE) is a cross-national panel survey of the older population. The first wave was conducted in 2004. We use Release 1 data, which is available from the SHARE website. ${ }^{3}$ This data release contains information on about 23,000 respondents aged 50 and over in 10 European countries (Sweden, Denmark, Germany, the Netherlands, France, Switzerland, Austria, Italy, Spain, and Greece; future releases will include data from Belgium and Israel).

Figure 1 shows the size of the joint working sample and the age/sex distribution, by country. ${ }^{4}$ The ELSA and HRS working samples have about the same size (10,800 and 9,400 individuals, respectively). The SHARE working sample has nearly 18,000 observation, but sample sizes per SHARE country are much smaller than those of HRS or ELSA, ranging from more than 2,000 in Sweden, Germany, Netherlands and Italy to less than 1,000 in Switzerland. There are about $25 \%$ more women than men in the joint data, which is mainly due to sex differences in mortality (i.e. there are simply more women than men in the older age groups). A larger proportion of women at older ages is clearly visible in all countries. Overall, the relative age and sex distributions are quite similar across countries, although there are a few exceptions, such as the relatively low number of individuals in the youngest age group in Germany and Greece.

--- about here Figure 1 ---

Note that, throughout this paper we use sampling weights to compute percentages, averages, and concentration indices. This is particularly important for HRS because - as described

\footnotetext{
${ }^{2}$ A detailed description of ELSA and first analyses using the 2002 data can be found in Marmot et al (2003).

${ }^{3}$ See www.share-project.org. SHARE is described in detail in Börsch-Supan et al. (2005).

${ }^{4}$ We have excluded all individuals younger than 55 from our joint sample because in the HRS there are only very few respondents in the 50 to 54 age group. This is due to the fact that the youngest sampled HRS cohort in 2002 was born in 1947.
} 
above - it combines several different samples drawn at different points in time, which may have suffered from differential attrition up to 2002.

\subsection{Education}

The education level of each respondent is measured by the ISCED-97 classification of the highest degree (OECD 1999). The ISCED-97 classification scheme has 7 different levels (0 to 6), ranging from pre-primary level of education (e.g. kindergarten) to the second stage of tertiary education (Ph.D.). We have recoded the initial ISCED codes into four broader education levels: "low" (pre-primary and primary education; ISCED 0 to 1), "medium" (lower secondary education; ISCED 2), "high" (upper secondary and post-secondary, non-tertiary education; ISCED 3 and 4), and "very high" (first and second stage of tertiary education; ISCED 5 and 6).

--- about here Table 1 ---

Table 1 shows the education levels by country and birth cohort. Younger cohorts have higher education levels. For instance, in the US, 20.6 percent of those born until 1935 had finished tertiary education. Among the younger cohorts, born in the 1940s, this proportion has increased to 26.8 percent. Table 1 also reveals cross-national differences in educational attainment. In particular in the southern European countries Greece, Italy, and Spain, there are relatively few older people with medium or high education. The most people with tertiary education can be found in Germany, Denmark, and Switzerland.

\subsection{Health}

A key issue that needs to be considered in all studies trying to understand the link between health and education (or other measures of socio-economic status such as income or wealth) is the measurement of health itself. The most common question on health found in social surveys is self-rated general health, asking respondents "How is your health in general?" and usually to be answered on a verbal 5-point scale with answer categories ranging from "excellent" to "poor" or from "very good" to "very bad". The former version is found in all three surveys used in this paper. As a simple and easily administered survey instrument, selfrated general health has proved to be a valuable indicator of an individuals' health, for 
instance as a powerful predictor of future health problems and mortality, even after controlling for medical history and risk factors (Idler \& Benyamini 1997).

However, self-rated health also has some disadvantages. One major concern with self-rated health is that respondents do not perceive the health self-assessment scale given to them as absolute. Individuals with the same true health status may have different reference levels against which they judge their health. For instance, respondents may be likely to report "poor" health only if they feel they are much less healthy than others of the same sex, age, education, or income. In cross-cultural studies there are additional concerns. Respondents from different countries and cultures may not only have different reference levels of health, but response categories may also have different connotations.

Following Jürges (2007a), we try to account for possible cross-cultural differences by computing a health index which is based on a common set of "objective" health information, such as chronic conditions, functional, ADL and IADL limitations. The health index ranges from 0 to 1 where 0 represents the worst observed health state and 1 represents "perfect" health. We use a set of 7 chronic conditions and 17 (I)ADL and functional limitations that are available in all three surveys to compute the health index. The absence of any conditions or limitations implies an index value of 1 . The presence of a condition reduces the health index by some given amount or percentage, the so-called disability weight. The disability weight of each condition or symptom is assumed to be the same for each respondent. We compute disability weights from within the combined HRS, ELSA, and SHARE samples by estimating generalized ordered probit regressions of self-reported health on the set dummy variables indicating the presence of each of the conditions and limitations. The health index is computed as the linear prediction from this regression, normalised to 0 for the worst observed health state and 1 for the best observed health state. We account for country specific reporting styles by modelling the ordered probit thresholds as a function of country of residence (i.e. there are basically fixed country effects at each threshold). Thus thresholds are allowed to vary across countries, while disability weights are constrained to be the same across countries (estimation details are available on request).

--- about here Figure 2 --- 
Figure 2 compares the country-averages of the physical health index with the average level of self-rated general health (recoded to the unit interval: 1 means "excellent" and 0 means "poor"). Countries to the right have higher average health indices; countries to the top have higher self-rated health levels. The figure contains some remarkable findings. First, the best average health can be found in Switzerland, Netherlands, Sweden, and Denmark, the worst health is found in Spain, Greece, the US, and England. Differences between countries are, with a few exceptions, statistically significant. Not significantly different are, for example, the average health indices in Greece and Spain, in France, Italy, and Germany, or in Denmark and Austria. Second, although self-rated general health and the physical health index are positively correlated, the correlation in not too strong $(r=0.53)$. Countries above the regression line (US, England, Sweden, Denmark) have higher self-rated health levels than expected on the basis of their physical health index, while others have lower levels. This could be due to country-specific reporting styles, as argued e.g. in Jürges (2007a), or due to omitted health variables (such as mental health).

\section{Education-related health inequalities in physical health}

\subsection{Description of cross-country differences}

Figure 3 shows the cross-national relationship between the level of education and average physical health, where a country's education is measured by the proportion of respondents with tertiary education. The relationship is generally positive $(r=0.55)$ : better educated countries are on average healthier. In particular the Mediterranean countries and England are characterised by low levels of education and health simultaneously.

--- about here Figure 3 ---

Figure 4 shows the relationship between formal education level and health within countries. Again, we find a generally positive relationship. The gradient looks steeper at lower education levels and flatter at higher education levels. In fact, in some countries, health does not improve beyond upper secondary education. This finding suggests decreasing marginal "returns" to education - similar to the decreasing marginal returns to income or wealth (e.g. Attanasio \& Hoynes 2000). Since education is measured ordinally, however, this 
interpretation should be treated with caution. Note also that we do not control for age (or cohort, respectively) in this graph, so that part of the relationship between formal education and health is due to older cohorts being less healthy and having lower education levels. Conditional on education, the US have the lowest health level among all countries followed by Germany. The highest health level conditional on education is found in Switzerland. The education-health gradients found in Figure 4 do not characterise overall health inequality because they contain no information about the proportion of respondents in each health category.

--- about here Figures 4 and 5 ---

Figure 5 shows the health concentration indices for each country together with their $90 \%$ confidence intervals. The health concentration index is statistically different from zero in all countries. The largest education-related health inequalities can be found in the Mediterranean and in the Anglo-Saxon countries, the lowest concentration indices are computed for Switzerland, Austria, and the Netherlands. The health concentration index is more than twice as large in Greece than in Switzerland. Pairwise t-tests show that the differences between the four countries with the lowest education-related health inequalities are never statistically significant at the 10 percent level. The same holds for the five countries with the largest health inequalities. Moreover, the four countries with the largest health inequalities (England, Italy, France, and Greece) have concentration indices which are significantly larger than those of the seven countries with the smallest health inequalities.

The above results are not easily comparable to those of earlier studies. For instance, Cavelaars et al. (1998) study education-related inequality in self-rated general health in 11 European countries including 9 of the countries in our study. They find the largest health inqualities (measured by the relative index of inequality) in Nordic countries and the smallest inequalities in Switzerland and Germany. Mediterranean countries and England have medium inequalities. The ranking of countries in their study appears to be more or less unrelated of the ranking in our data. However, there are many reasons why this could be the case: in particular, Cavelaars et al. use different national surveys that are harmonised ex-post, spanning nine years, with different question formats for self-rated health, and the study covers respondents aged 25 to 69, thus excluding individuals aged 70 and over. Van Doorslaer and Koolman (2004) compute concentration indices for income-related inequality in self-rated health using data from the 
1996 ECHP (thus covering the whole population except children younger than 16). They find the largest inequalities in England and Greece and the smallest inequalities in Germany and the Netherlands. Italy and France, which have large education-related inequalities in health in our data, have medium inequalities.

With average physical health and a measure of health inequalities at hand, it seems natural to study whether we can find evidence for an efficiency-equity trade-off across countries. This is relevant for public policy because if such a trade-off was found, one might be willing to sacrifice some equality in health for higher overall health levels (or vice versa). However, in our data we actually find the opposite of such a trade-off. Figure 6 plots health inequality against average health. The relationship is clearly negative $(r=-0.82)$ : healthier countries are also less unequal.

\section{--- about here Figure 6 ---}

\subsection{Decomposition by covariates}

The final step of our analysis is the decomposition of education related inequalities in health into its sources. First and foremost, we wish to control for the effects of important correlates of education: age and sex, income, wealth, and health behaviours such as smoking. We already mentioned that older cohorts are at the same time sicker and less educated. Better educated respondents are also wealthier on average and are less prone to pursue risky behaviours. We will examine how much of the education-related inequality in health is due to these factors.

In order to compute the health elasticities of each covariate, we specify and estimate a linear health production function (see Equation (2)) which includes - apart from education itself 11 dummy variables for age and sex (the six age groups are: 55-59, 60-64, 65-69, 70-74, 75$79,80+), \log$ equivalised household income, log equivalised household wealth, marital status, employment status, immigrant status, and smoking history (whether current smoker, former smoker or never smoked, separately for men and women). The health regression results are mostly according to expectations (see Table A1 in the Appendix). Average health increases in education and wealth. Conditional on education and wealth, current income has a significant positive coefficient only in the US. In some countries (Switzerland, UK), the coefficient of 
current income even becomes negative and significant when education and wealth are controlled for. Widowed and divorced respondents have lower health levels than married and single respondents. Respondents who are working are significantly healthier than those who do not work. Apparently, whether to include this probably highly endogenous variable in the health regression is a contentious issue (even more so than for income and wealth). Since one cannot give this health equation a structural equation, one would ideally want to estimate a reduced form equation (including only exogenous variables). However, truly exogenous covariates of education and health are extremely hard to find.

Foreign born respondents are healthier than natives in some countries (US, Austria) and less healthy in other countries (Sweden, Switzerland, and Denmark). Male former smokers are significantly less healthy in most countries than men who never smoked. Exceptions are Germany, the Netherlands, France, and Greece. Female respondents who are former smokers are also less healthy on average in most countries, but the relationship is significant only in Denmark, Greece, the US, and England. The relationship between being a current smoker (surely also an endogenous variable) and physical health is fairly ambiguous.

Further ingredients into the decomposition analysis are the concentration indices of the covariates in relation to education. In other words, we need to know how unequal covariates are distributed across different education groups. Note that the concentration indices are based on unconditional covariances between the covariate and the fractional education rank. Positive values mean that that the respective covariate is positively associated with education. Detailed results can be found in Appendix Table A2. Here, we mention only a few findings. Men are better educated than women and younger respondents are better educated than older respondents. Both relationships appear to be weakest in the US. Income and wealth are concentrated among the better educated. These two concentrations are largest in the US and England. Working individuals are also most often found among the better educated. The relationship is strongest in Austria and Italy, i.e. in countries with rather low mandatory and/or factual retirement ages, and it is weakest in the US. In Spain, Italy, Sweden, and Denmark, the foreign born are better educated than natives and in the US, France, and Switzerland the opposite holds. Somewhat surprisingly male former and current smokers are mostly found among the better educated. One exception is Sweden, where both groups are groups are more prominent among the less educated. However, using different data covering the whole population, Cutler \& Glaeser (2006) find qualitatively similar results. Female 
former and current smokers are found among the better educated particularly in the Mediterranean countries Italy, Spain, Greece, and France, while in the US, England, Denmark and Switzerland, former and current female smokers are uniformly found among the less educated.

With health elasticities and concentration indices for covariates at hand, we are now able to decompose health inequality into its components (see Equation (5)). The results are shown in Table 2 - expressed in percentage contributions of each covariate. The contribution of a covariate to education-related health inequality can be positive or negative. Variables that improve health and that are more concentrated among the better educated (such as wealth) as well as variables that deteriorate health and that are less concentrated among the better educated (such as age) increase education-related inequalities in health. Variables that improve health but that are more concentrated among the less educated as well as variables that deteriorate health and that are more concentrated among the better educated decrease education-related inequalities in health.

Table 2 shows that in 9 out of 12 countries, education itself, or omitted variables correlated with education, explain less than 50 percent of the education-related inequality in health. Put differently, the covariates of education included in the health production function explain more than half of the measured inequality in health. With the exception of the US and England, age and sex, reflecting the demographic composition of the education groups, are the most important covariates of education that explains inequalities in health. The health inequality literature often denotes inequalities that are due to age-sex differences in education or income as "unavoidable", i.e. as something that health policy cannot influence. The concentration index is then "standardised" in the sense that the health inequality related to age and sex is subtracted from overall inequality. Surely this is a contentious issue in particular in cross-country comparisons, as it is not entirely clear why the pace with which health declines in age or sex differences in health should not be amenable to policy interventions. For instance, although it might not be possible to change the (education-related) age distribution of the (older) population, it is possible to target health policies to older adults, changing the health elasticity of age. As argued convincingly by Gravelle (2003), the distinction between "standardising" and policy relevant variables depends on the policy context and is hence to some degree arbitrary. 
Still, we followed the route taken in most of the health inequality literature and compute concentration indices net of age and sex differences in education and health (denoted $I^{*}$, see last row in Table 2). $I^{*}$ is simply computed by $\mathrm{C}$ times one minus the percentage contribution of age and sex, for instance $0.021 \times(1-0.394)=0.013$ for Austria. Using $I^{*}$ as a comparative measure of education-related inequalities in health hardly affects the country ranking, with three notable exceptions. Since age and sex contribute relatively little to $C$, Anglo-Saxon countries now have the largest health inequalities. In Greece, age and sex contribute more than 50 percent to education-related health inequality, which is by far the largest percentage among all countries. Subtracting this contribution from the concentration index moves Greece to a middle rank, with $I^{*}$ being in the range of countries such as Germany, the Netherlands, and Denmark. Switzerland and Austria remain the countries with the smallest inequalities in health also after controlling for age and sex differences across education groups,.

Overall, differences between countries in terms of the relative size of the concentration index remain (it is more than twice as large in England than in Switzerland), but the differences are less significant statistically. Pairwise t-tests show that it is mainly England and the US which have statistically higher concentration indices than all other countries except France and Spain. France has significantly larger concentration indices than the four countries with the lowest "avoidable" health inequality Switzerland, Austria, Germany, and the Netherlands. Spain and Italy have significantly larger concentration indices than the two most equal countries.

We now discuss which covariates contribute most to the explanation of "avoidable" health inequality. As mentioned before, in most countries, much of the education-related inequality in health is due to education itself (or omitted variables correlated with education). Two important correlates of education are income and wealth. Income and wealth can affect health in several ways - both in the long-run and in the short-run. The most obvious short-run effect is that wealth allows to purchase both better access to health care and access to better health care. Also, rich people can afford to live in healthier environments. Very long-lasting effects of wealth on health, mainly in-utero and early childhood events and conditions, have recently moved into the focus of health researchers (e.g. Doblhammer \& Vaupel 2001).

We find surprisingly large cross-national differences in the contribution of income and wealth to education-related inequalities in health. In the US, income and wealth together account for 
nearly $40 \%$ of the avoidable education-related health inequality, which is by far the largest contribution across all countries. In Germany, the Netherlands, and France, the contribution of income and wealth is about 20 to $25 \%$, and in Spain and Switzerland it is virtually zero. Overall, wealth appears to be more important in explaining health inequality than current income, which seems plausible given that wealth reflects lifetime economic resources better than current income.

Employment status also explains a large proportion of health inequality, although this finding is a bit difficult to interpret as health is more likely to affect employment status than vice versa because bad health limits the ability to work. The negative contribution of smoking found in most countries is surprising since much of the debate on the causal effects of education on health is in terms of more favourable health behaviors, either because education informs about the dangers and benefits of certain behaviours and thus alters health inputs, or because education itself increases the time horizon thus alters behaviour (Kenkel 1991, Sander 1995).

\section{Summary}

In this paper we combine three comparable data sets on older populations in the US, England, and 10 continental European countries (HRS, ELSA, and SHARE) to measure and decompose education-related inequality in health across these countries. Although the restriction to the older population is a disadvantage compared to similar studies, the data sets we use have several important advantages. Perhaps the main advantage is that health information is very detailed in all three surveys. This allows us to use a fairly comprehensive and comparable measure of physical health as our dependent variable. While others have mainly used selfrated health or more or less plausible external cardinalisations of self-rated health, we have constructed a continuous health index based on respondent's information on ever diagnosed chronic conditions, as well as functional, ADL and IADL limitations. Since we derive disability weights from regressions of self-rated health on indicator variables of conditions and limitations, our health index combines the advantage of detailed, quasi-objective information on health states with subjective judgements about the severity of these health states. 
Our study contains a number of important findings: First, better education is strongly correlated with better health both across and within countries. A positive gradient can be found in all countries in our dataset. The health concentration index as our measure of education-related inequality in health is significantly different from zero in all countries in our data. This holds independent of whether inequality is age-sex standardised or not. Second, education-related inequality in health is significantly larger in Mediterranean and AngloSaxon countries than in Nordic or Western European countries. The differences are generally weaker when the concentration index is age-sex standardised but remain fairly sizeable. The concentration index in the country with the largest education-related health inequality (UK) is about double the size of the concentration index of the country with the smallest health inequality (Switzerland). Third, we find no trade-off between health levels and equity. Countries with higher average levels of health usually have lower levels of inequality in health.

Finally, turning to the sources of education-related inequality in health, we find that income and wealth effects are only moderately important. In most countries, they account for at most $25 \%$ of the age-sex standardised concentration index. An exception in this respect are the US, where income and wealth account for $40 \%$ of the education-related health inequality. Another causal pathway of education on health identified in the theoretical literature is health behaviours. Somewhat to our surprise, we find that behavioural risks (here: smoking) contribute surprisingly little to the explanation of why inequalities in health favour the better educated. 


\section{References}

Adams, S.J. (2002): Educational attainment and health: Evidence from a sample of older adults, Education Economics 10, 97-109.

Arendt, J.N. (2005): Does education cause better health? A panel data analysis using school reform for identification, Economics of Education Review 24, 149-160.

Attanasio, O.P. and H. Hoynes, (2000), 'Differential Mortality and Wealth Accumulation', Journal of Human Resources 35, 1-29.

Becker, G.S. and C.B. Mulligan (1997): The endogenous determination of time preference, Quarterly Journal of Economics 112, 729-758.

Börsch-Supan, A., Brugiavini A., Jürges, H., Mackenbach, J., Siegrist J., and Weber, G. (eds) (2005): Health, Ageing and Retirement in Europe - First Results from the Survey of Health, Ageing and Retirement in Europe. Mannheim: MEA.

Cavelaars, A.E., Kunst, A.E., Geurts, J.J. et al (1998): Differences in self reported morbidity by educational level: a comparison of 11 western European countries. Journal of Epidemiology and Community Health 1998, 219-227.

Cutler, D.M. \& Glaeser, E.L. (2006): Why Do Europeans Smoke More Than Americans? NBER Working Paper 12124

Deaton, A. (2002): Policy implications of the gradient of health and wealth, Health Affairs 21 (2), 13-30.

Deaton, A. (2003): Health, Income and Inequality. NBER Reporter, Spring 2003.

Doblhammer, G. and J. Vaupel (2001): Lifespan depends on month of birth. Proceedings of the National Academy of Sciences 98: 2934-2939.

Etilé, F., Milcent, C. (2006): Income-related reporting heterogeneity in subjective health: evidence from France. Health Economics 15: 965-981.

Gravelle, H. (2003): Measuring income related inequality in health: standardisation and the partial concentration index. Health Economics 12: 803-819.

Grossman, M. (2005): Education and nonmarket outcomes, NBER Working Paper No. 11582.

Grossman M., Kaestner R. (1997): The effects of education on health. Pp. 69-123 in: Behrman R, Stacey N (Eds.), The Social Benefits of Education. Ann Arbor, MI: University of Michigan Press.

Idler, E.L. \& Benyamini, Y. (1997): Self-rated health and mortality: A review of twenty-seven community studies. Journal of Health and Social Behavior 38, 21-37.

Jürges, H. (2007a): True health vs. response styles: Exploring cross-country differences in self-reported health. Health Economics 16, 163-178.

Jürges, H. (2007b): Self-assessed health, reference levels, and mortality. Forthcoming in Applied Economics

Juster, T. and R. Suzman (1995): An overview of the Health and Retirement Study. Journal of Human Resources 30, S7-S56.

Kenkel, D. (1991): Health Behavior, Health Knowledge, and Schooling. Journal of Political Economy 99: $287-$ 305.

Lleras-Muney, A. (2005): The relationship between education and adult mortality in the United States, Review of Economic Studies 72, 189-221.

Marmot, M., Banks, J., Blundell, R. Lessof, C. Nazroo, J. (2003): Health, wealth and lifestyles of the older population in England: The English Longitudinal Study of Ageing. London: Institute for Fiscal Studies.

OECD (1999): Classifying Educational Programmes. Manual for ISCED-97 Implementation in OECD Countries. 1999 edition. Paris: OECD.

Sander, W. (1995): Schooling and Quitting Smoking. Review of Economics and Statistics 77, 191-199.

Wagstaff, A., Doorslaer, E.v., Watanabe, N. (2003): On the decomposing the causes of health sector inequalities with an application to malnutrition inequalities in Vietnam. Journal of Econometrics 112, 207-223

Van Doorslaer, E.., Wagstaff, A., Bleichrodt, H. et al (1997): Income-related inequalities in health: some international comparisons. Journal of Health Economics 16: 93-112. 
Van Doorslaer, E. \& Gerdtham, U.-G. (2003): Does inequality in self-assessed health predict inequality in survival by income? Evidence from Swedish Data. Social Science \& Medicine 57, 1621-1629.

Van Doorslaer, E.., Koolman, X (2004): Explaining the differences in income-related health inequalities across European countries. Health Economics 13: 609-628. 
Table 1: Education Levels, by country and birth cohort

\begin{tabular}{lcccccccc}
\hline & \multicolumn{3}{c}{ Born 1935 and before } & \multicolumn{3}{c}{ Born 1936 to 1949 } \\
\cline { 2 - 9 } & \multicolumn{1}{c}{ Low } & \multicolumn{1}{c}{ Medium } & High & Very high & Low & Medium & High & Very high \\
\hline Austria & 0.2 & 43.0 & 41.4 & 15.5 & 0.1 & 26.6 & 52.6 & 20.7 \\
Germany & 1.9 & 34.2 & 47.4 & 16.6 & 0.7 & 13.0 & 59.1 & 27.2 \\
Sweden & 59.9 & 12.1 & 16.5 & 11.5 & 30.7 & 18.3 & 27.4 & 23.5 \\
Netherlands & 32.2 & 36.5 & 18.5 & 12.8 & 14.1 & 43.3 & 22.1 & 20.5 \\
Spain & 85.1 & 9.0 & 1.9 & 4.1 & 59.6 & 21.4 & 9.8 & 9.3 \\
Italy & 72.9 & 11.1 & 11.8 & 4.3 & 46.9 & 22.7 & 21.9 & 8.5 \\
France & 63.9 & 8.7 & 15.8 & 11.6 & 39.8 & 8.2 & 33.0 & 18.9 \\
Denmark & 0.0 & 40.4 & 36.7 & 22.9 & 0.0 & 19.5 & 46.5 & 34.0 \\
Greece & 79.2 & 7.9 & 9.1 & 3.8 & 48.1 & 12.2 & 23.4 & 16.2 \\
Switzerland & 29.8 & 35.7 & 18.0 & 16.5 & 19.6 & 26.7 & 24.2 & 29.5 \\
United States & 5.2 & 17.1 & 57.1 & 20.6 & 3.0 & 10.7 & 59.6 & 26.8 \\
UK & 51.4 & 23.5 & 18.9 & 6.2 & 3.9 & 42.5 & 41.0 & 12.6 \\
\hline
\end{tabular}

Note - Low $=$ ISCED 0 to $1 ;$ Medium $=$ ISCED 2; High $=$ ISCED 3 to 4; Very High = ISCED 5 to 6.

Table 2: percentage contribution of covariates to education-related inequality in health

\begin{tabular}{lrrrrrrrrrrrr}
\hline \multicolumn{1}{c}{} & $\mathrm{AT}$ & $\mathrm{DE}$ & $\mathrm{SE}$ & $\mathrm{NL}$ & $\mathrm{ES}$ & $\mathrm{IT}$ & $\mathrm{FR}$ & $\mathrm{DK}$ & $\mathrm{GR}$ & $\mathrm{CH}$ & $\mathrm{US}$ & $\mathrm{UK}$ \\
\hline Education & 48.7 & 29.0 & 38.1 & 34.9 & 51.8 & 54.9 & 45.5 & 45.6 & 28.0 & 61.6 & 44.3 & 44.1 \\
Age \& Sex & 39.4 & 38.1 & 34.6 & 27.8 & 36.3 & 36.5 & 35.9 & 35.6 & 54.7 & 33.5 & 8.9 & 19.3 \\
Income & -0.6 & 3.8 & 3.5 & 2.2 & -0.7 & 0.3 & 1.7 & -5.1 & 2.4 & -8.8 & 16.4 & -3.1 \\
Wealth & 3.5 & 10.8 & 1.3 & 14.2 & -0.0 & 6.5 & 15.1 & 9.7 & 3.0 & 5.5 & 17.4 & 12.7 \\
Marital status & 6.1 & 5.6 & 0.2 & 5.0 & 0.3 & -0.7 & -0.6 & -2.9 & 7.0 & 0.4 & 0.7 & 0.3 \\
Working & 11.6 & 12.0 & 22.8 & 17.8 & 11.7 & 7.2 & 4.0 & 21.5 & 4.5 & 11.8 & 14.3 & 27.1 \\
Immigrant & 0.1 & 0.2 & -0.8 & 0.0 & 1.2 & 0.4 & 0.0 & -1.3 & -0.0 & 1.3 & -2.4 & -0.1 \\
Smoking & -8.7 & 0.6 & 0.3 & -1.9 & -0.6 & -5.1 & -1.6 & -3.1 & 0.4 & -5.1 & 0.4 & -0.3 \\
& & & & & & & & & & & & \\
$C$ & 0.021 & 0.025 & 0.026 & 0.022 & 0.032 & 0.033 & 0.035 & 0.025 & 0.036 & 0.017 & 0.028 & 0.032 \\
$I^{*}$ & 0.013 & 0.016 & 0.017 & 0.016 & 0.020 & 0.021 & 0.023 & 0.016 & 0.016 & 0.012 & 0.025 & 0.026 \\
\hline
\end{tabular}




\section{Appendix}

Table A1: Health regressions (dependent variable: physical health index)

\begin{tabular}{|c|c|c|c|c|c|c|c|c|c|c|c|c|}
\hline & AT & $\mathrm{DE}$ & SE & $\mathrm{NL}$ & ES & IT & FR & DK & GR & $\mathrm{CH}$ & US & UK \\
\hline isced2 & & & $\begin{array}{l}0.035^{\star *} \\
(3.78)\end{array}$ & $\begin{array}{l}0.023^{*} \\
(2.51)\end{array}$ & $\begin{array}{l}0.065^{\star \star} \\
(5.41)\end{array}$ & $\begin{array}{l}0.063^{* *} \\
(5.80)\end{array}$ & $\begin{array}{l}0.026 \\
(1.45)\end{array}$ & & $\begin{array}{l}0.037^{*} \\
(2.35)\end{array}$ & $\begin{array}{l}0.045^{\star *} \\
(3.15)\end{array}$ & $\begin{array}{l}0.034^{* *} \\
(3.76)\end{array}$ & $\begin{array}{l}0.017^{\star \star} \\
(3.12)\end{array}$ \\
\hline isced3/4 & $\begin{array}{l}0.053^{* *} \\
(5.28)\end{array}$ & $\begin{array}{l}0.017 \\
(1.81)\end{array}$ & $\begin{array}{l}0.024^{* *} \\
(2.96)\end{array}$ & $\begin{array}{l}0.032^{* *} \\
(3.12)\end{array}$ & $\begin{array}{l}0.067^{* *} \\
(3.49)\end{array}$ & $\begin{array}{l}0.059^{* *} \\
(5.35)\end{array}$ & $\begin{array}{l}0.043^{* *} \\
(3.41)\end{array}$ & $\begin{array}{l}0.035^{\star *} \\
(2.98)\end{array}$ & $\begin{array}{l}0.034^{*} \\
(2.50)\end{array}$ & $\begin{array}{l}0.040^{*} \\
(2.49)\end{array}$ & $\begin{array}{l}0.069^{* *} \\
(8.22)\end{array}$ & $\begin{array}{l}0.045^{\star *} \\
(7.96)\end{array}$ \\
\hline isced5/6 & $\begin{array}{l}0.032^{*} \\
(2.48)\end{array}$ & $\begin{array}{l}0.035^{\star *} \\
(2.99)\end{array}$ & $\begin{array}{l}0.041^{\text {** }} \\
(4.53)\end{array}$ & $\begin{array}{l}0.036^{* *} \\
(3.14)\end{array}$ & $\begin{array}{l}0.062^{* *} \\
(3.50)\end{array}$ & $\begin{array}{l}0.064^{* *} \\
(3.69)\end{array}$ & $\begin{array}{l}0.062^{* *} \\
(4.18)\end{array}$ & $\begin{array}{l}0.047^{* *} \\
(3.63)\end{array}$ & $\begin{array}{l}0.032 \\
(1.87)\end{array}$ & $\begin{array}{l}0.054^{* *} \\
(3.40)\end{array}$ & $\begin{array}{l}0.089^{* *} \\
(9.88)\end{array}$ & $\begin{array}{l}0.061^{* *} \\
(7.90)\end{array}$ \\
\hline men $60-64$ & $\begin{array}{l}0.026 \\
(1.27)\end{array}$ & $\begin{array}{l}-0.002 \\
(0.14)\end{array}$ & $\begin{array}{l}-0.012 \\
(0.92)\end{array}$ & $\begin{array}{l}0.015 \\
(1.02)\end{array}$ & $\begin{array}{l}-0.004 \\
(0.18)\end{array}$ & $\begin{array}{l}-0.013 \\
(0.76)\end{array}$ & $\begin{array}{l}-0.035 \\
(1.44)\end{array}$ & $\begin{array}{l}0.015 \\
(0.74)\end{array}$ & $\begin{array}{l}-0.007 \\
(0.33)\end{array}$ & $\begin{array}{l}0.011 \\
(0.48)\end{array}$ & $\begin{array}{l}-0.002 \\
(0.38)\end{array}$ & $\begin{array}{l}-0.007 \\
(0.80)\end{array}$ \\
\hline men $65-69$ & $\begin{array}{l}0.010 \\
(0.46)\end{array}$ & $\begin{array}{l}-0.010 \\
(0.59)\end{array}$ & $\begin{array}{l}0.023 \\
(1.49)\end{array}$ & $\begin{array}{l}0.012 \\
(0.74)\end{array}$ & $\begin{array}{l}0.007 \\
(0.31)\end{array}$ & $\begin{array}{l}-0.039^{*} \\
(2.12)\end{array}$ & $\begin{array}{l}-0.037 \\
(1.44)\end{array}$ & $\begin{array}{l}0.010 \\
(0.44)\end{array}$ & $\begin{array}{l}-0.039 \\
(1.66)\end{array}$ & $\begin{array}{l}-0.007 \\
(0.25)\end{array}$ & $\begin{array}{l}-0.013 \\
(1.85)\end{array}$ & $\begin{array}{l}0.028^{* *} \\
(3.09)\end{array}$ \\
\hline men $70-74$ & $\begin{array}{l}-0.024 \\
(1.03)\end{array}$ & $\begin{array}{l}-0.030 \\
(1.47)\end{array}$ & $\begin{array}{l}-0.009 \\
(0.56)\end{array}$ & $\begin{array}{l}-0.003 \\
(0.16)\end{array}$ & $\begin{array}{l}-0.010 \\
(0.42)\end{array}$ & $\begin{array}{l}-0.067^{* *} \\
(3.60)\end{array}$ & $\begin{array}{l}-0.081^{* *} \\
(3.05)\end{array}$ & $\begin{array}{l}-0.014 \\
(0.54)\end{array}$ & $\begin{array}{l}-0.042 \\
(1.64)\end{array}$ & $\begin{array}{l}-0.025 \\
(0.87)\end{array}$ & $\begin{array}{l}-0.021^{* *} \\
(2.69)\end{array}$ & $\begin{array}{l}0.026^{\star *} \\
(2.65)\end{array}$ \\
\hline men $75-79$ & $\begin{array}{l}-0.057^{*} \\
(2.20)\end{array}$ & $\begin{array}{l}-0.070^{\star *} \\
(3.38)\end{array}$ & $\begin{array}{l}-0.058^{\star *} \\
(3.27)\end{array}$ & $\begin{array}{l}-0.057^{\star *} \\
(3.07)\end{array}$ & $\begin{array}{l}-0.054^{*} \\
(2.15)\end{array}$ & $\begin{array}{l}-0.077^{\star *} \\
(3.28)\end{array}$ & $\begin{array}{l}-0.165^{* *} \\
(5.93)\end{array}$ & $\begin{array}{l}-0.071^{* *} \\
(2.61)\end{array}$ & $\begin{array}{l}-0.130^{\star *} \\
(4.46)\end{array}$ & $\begin{array}{l}-0.036 \\
(1.09)\end{array}$ & $\begin{array}{l}-0.035^{\star *} \\
(3.90)\end{array}$ & $\begin{array}{l}-0.002 \\
(0.18)\end{array}$ \\
\hline men $80+$ & $\begin{array}{l}-0.067^{*} \\
(2.40)\end{array}$ & $\begin{array}{l}-0.136^{* *} \\
(5.78)\end{array}$ & $\begin{array}{l}-0.119^{\star *} \\
(7.13)\end{array}$ & $\begin{array}{l}-0.048^{*} \\
(2.40)\end{array}$ & $\begin{array}{l}-0.139^{\star *} \\
(5.59)\end{array}$ & $\begin{array}{l}-0.132^{\star *} \\
(5.71)\end{array}$ & $\begin{array}{l}-0.156^{* *} \\
(5.53)\end{array}$ & $\begin{array}{l}-0.099^{\star *} \\
(3.62)\end{array}$ & $\begin{array}{l}-0.210^{\star *} \\
(7.20)\end{array}$ & $\begin{array}{l}-0.069^{*} \\
(2.16)\end{array}$ & $\begin{array}{l}-0.070^{\star *} \\
(7.51)\end{array}$ & $\begin{array}{l}-0.043^{\star *} \\
(3.91)\end{array}$ \\
\hline women $55-59$ & $\begin{array}{l}-0.002 \\
(0.12)\end{array}$ & $\begin{array}{l}0.007 \\
(0.36)\end{array}$ & $\begin{array}{l}-0.030^{*} \\
(2.05)\end{array}$ & $\begin{array}{l}-0.023 \\
(1.44)\end{array}$ & $\begin{array}{l}-0.037 \\
(1.71)\end{array}$ & $\begin{array}{l}-0.061^{* *} \\
(3.23)\end{array}$ & $\begin{array}{l}-0.025 \\
(1.08)\end{array}$ & $\begin{array}{l}-0.042 \\
(1.85)\end{array}$ & $\begin{array}{l}-0.022 \\
(0.85)\end{array}$ & $\begin{array}{l}0.018 \\
(0.72)\end{array}$ & $\begin{array}{l}-0.018^{*} \\
(2.54)\end{array}$ & $\begin{array}{l}-0.020^{*} \\
(2.17)\end{array}$ \\
\hline women $60-64$ & $\begin{array}{l}0.001 \\
(0.06)\end{array}$ & $\begin{array}{l}0.005 \\
(0.27)\end{array}$ & $\begin{array}{l}-0.025 \\
(1.63)\end{array}$ & $\begin{array}{l}-0.006 \\
(0.36)\end{array}$ & $\begin{array}{l}-0.077^{\star *} \\
(3.37)\end{array}$ & $\begin{array}{l}-0.074^{* *} \\
(3.74)\end{array}$ & $\begin{array}{l}-0.030 \\
(1.16)\end{array}$ & $\begin{array}{l}-0.034 \\
(1.36)\end{array}$ & $\begin{array}{l}-0.050 \\
(1.95)\end{array}$ & $\begin{array}{l}-0.031 \\
(1.16)\end{array}$ & $\begin{array}{l}-0.021^{* *} \\
(2.69)\end{array}$ & $\begin{array}{l}-0.006 \\
(0.56)\end{array}$ \\
\hline women $65-69$ & $\begin{array}{l}-0.044 \\
(1.92)\end{array}$ & $\begin{array}{l}-0.017 \\
(0.89)\end{array}$ & $\begin{array}{l}-0.004 \\
(0.23)\end{array}$ & $\begin{array}{l}-0.017 \\
(0.90)\end{array}$ & $\begin{array}{l}-0.069^{* *} \\
(2.95)\end{array}$ & $\begin{array}{l}-0.088^{* *} \\
(4.28)\end{array}$ & $\begin{array}{l}-0.089^{* *} \\
(3.37)\end{array}$ & $\begin{array}{l}-0.019 \\
(0.72)\end{array}$ & $\begin{array}{l}-0.083^{* *} \\
(3.16)\end{array}$ & $\begin{array}{l}-0.010 \\
(0.37)\end{array}$ & $\begin{array}{l}-0.025^{\star *} \\
(3.11)\end{array}$ & $\begin{array}{l}-0.005 \\
(0.53)\end{array}$ \\
\hline women $70-74$ & $\begin{array}{l}-0.055^{*} \\
(2.45)\end{array}$ & $\begin{array}{l}-0.043^{*} \\
(2.06)\end{array}$ & $\begin{array}{l}-0.046^{\star *} \\
(2.63)\end{array}$ & $\begin{array}{l}-0.014 \\
(0.76)\end{array}$ & $\begin{array}{l}-0.118^{\star *} \\
(5.07)\end{array}$ & $\begin{array}{l}-0.148^{* *} \\
(7.20)\end{array}$ & $\begin{array}{l}-0.116^{* *} \\
(4.30)\end{array}$ & $\begin{array}{l}-0.023 \\
(0.79)\end{array}$ & $\begin{array}{l}-0.136^{\star *} \\
(4.94)\end{array}$ & $\begin{array}{l}-0.038 \\
(1.27)\end{array}$ & $\begin{array}{l}-0.052^{\star *} \\
(6.05)\end{array}$ & $\begin{array}{l}-0.039^{* *} \\
(3.61)\end{array}$ \\
\hline women $75-79$ & $\begin{array}{l}-0.114^{* *} \\
(4.63)\end{array}$ & $\begin{array}{l}-0.102^{\star *} \\
(4.78)\end{array}$ & $\begin{array}{l}-0.074^{* *} \\
(4.02)\end{array}$ & $\begin{array}{l}-0.088^{\star *} \\
(4.36)\end{array}$ & $\begin{array}{l}-0.172^{\star *} \\
(6.99)\end{array}$ & $\begin{array}{l}-0.171^{* *} \\
(7.81)\end{array}$ & $\begin{array}{l}-0.142^{* *} \\
(5.07)\end{array}$ & $\begin{array}{l}-0.069^{*} \\
(2.44)\end{array}$ & $\begin{array}{l}-0.212^{\star *} \\
(7.17)\end{array}$ & $\begin{array}{l}-0.088^{* *} \\
(2.96)\end{array}$ & $\begin{array}{l}-0.063^{\star *} \\
(6.73)\end{array}$ & $\begin{array}{l}-0.048^{* *} \\
(4.30)\end{array}$ \\
\hline women $80+$ & $\begin{array}{l}-0.156^{* *} \\
(6.40)\end{array}$ & $\begin{array}{l}-0.171^{* *} \\
(8.05)\end{array}$ & $\begin{array}{l}-0.199^{* *} \\
(11.74)\end{array}$ & $\begin{array}{l}-0.173^{* *} \\
(9.04)\end{array}$ & $\begin{array}{l}-0.260^{* *} \\
(10.99)\end{array}$ & $\begin{array}{l}-0.202^{* *} \\
(9.52)\end{array}$ & $\begin{array}{l}-0.230^{* *} \\
(8.40)\end{array}$ & $\begin{array}{l}-0.185^{\star *} \\
(6.71)\end{array}$ & $\begin{array}{l}-0.276^{* *} \\
(9.23)\end{array}$ & $\begin{array}{l}-0.111^{* *} \\
(3.71)\end{array}$ & $\begin{array}{l}-0.109^{* *} \\
(11.38)\end{array}$ & $\begin{array}{l}-0.098^{* *} \\
(8.83)\end{array}$ \\
\hline income & $\begin{array}{l}-0.001 \\
(0.32)\end{array}$ & $\begin{array}{l}0.006 \\
(1.47)\end{array}$ & $\begin{array}{l}0.007 \\
(1.55)\end{array}$ & $\begin{array}{l}0.003 \\
(0.92)\end{array}$ & $\begin{array}{l}-0.003 \\
(0.63)\end{array}$ & $\begin{array}{l}0.001 \\
(0.23)\end{array}$ & $\begin{array}{l}0.004 \\
(0.87)\end{array}$ & $\begin{array}{l}-0.009 \\
(1.77)\end{array}$ & $\begin{array}{l}0.006 \\
(1.04)\end{array}$ & $\begin{array}{l}-0.011^{*} \\
(2.06)\end{array}$ & $\begin{array}{l}0.018^{\star *} \\
(9.41)\end{array}$ & $\begin{array}{l}-0.006^{*} \\
(2.23)\end{array}$ \\
\hline wealth & $\begin{array}{l}0.002^{*} \\
(2.24)\end{array}$ & $\begin{array}{l}0.006^{* *} \\
(6.52)\end{array}$ & $\begin{array}{l}0.002^{* *} \\
(2.67)\end{array}$ & $\begin{array}{l}0.006^{\star *} \\
(7.59)\end{array}$ & $\begin{array}{l}0.005^{\star *} \\
(3.49)\end{array}$ & $\begin{array}{l}0.004^{* *} \\
(3.86)\end{array}$ & $\begin{array}{l}0.012^{* *} \\
(7.23)\end{array}$ & $\begin{array}{l}0.005^{* *} \\
(6.13)\end{array}$ & $\begin{array}{l}0.004^{* *} \\
(3.00)\end{array}$ & $\begin{array}{l}0.003^{*} \\
(2.49)\end{array}$ & $\begin{array}{l}0.007^{* *} \\
(17.83)\end{array}$ & $\begin{array}{l}0.007^{\star *} \\
(14.92)\end{array}$ \\
\hline divorced & $\begin{array}{l}-0.029 \\
(0.89)\end{array}$ & $\begin{array}{l}-0.012 \\
(0.35)\end{array}$ & $\begin{array}{l}-0.024 \\
(0.54)\end{array}$ & $\begin{array}{l}-0.008 \\
(0.28)\end{array}$ & $\begin{array}{l}-0.026 \\
(0.82)\end{array}$ & $\begin{array}{l}-0.022 \\
(0.62)\end{array}$ & $\begin{array}{l}-0.059 \\
(1.46)\end{array}$ & $\begin{array}{l}-0.117^{\star *} \\
(3.23)\end{array}$ & $\begin{array}{l}-0.064 \\
(1.33)\end{array}$ & $\begin{array}{l}-0.020 \\
(0.52)\end{array}$ & $\begin{array}{l}-0.008 \\
(1.56)\end{array}$ & $\begin{array}{l}-0.018^{\star *} \\
(2.66)\end{array}$ \\
\hline single & $\begin{array}{l}0.012 \\
(0.35)\end{array}$ & $\begin{array}{l}0.009 \\
(0.24)\end{array}$ & $\begin{array}{l}-0.011 \\
(0.24)\end{array}$ & $\begin{array}{l}-0.018 \\
(0.59)\end{array}$ & $\begin{array}{l}0.018 \\
(0.42)\end{array}$ & $\begin{array}{l}0.009 \\
(0.20)\end{array}$ & $\begin{array}{l}0.065 \\
(1.51)\end{array}$ & $\begin{array}{l}0.112^{\text {** }} \\
(2.97)\end{array}$ & $\begin{array}{l}0.066 \\
(1.22)\end{array}$ & $\begin{array}{l}0.036 \\
(0.83)\end{array}$ & $\begin{array}{l}0.004 \\
(0.43)\end{array}$ & $\begin{array}{l}0.013 \\
(1.56)\end{array}$ \\
\hline widowed & $\begin{array}{l}-0.025^{*} \\
(2.15)\end{array}$ & $\begin{array}{l}-0.021^{*} \\
(2.22)\end{array}$ & $\begin{array}{l}-0.006 \\
(0.70)\end{array}$ & $\begin{array}{l}-0.022^{*} \\
(2.37)\end{array}$ & $\begin{array}{l}-0.006 \\
(0.52)\end{array}$ & $\begin{array}{l}-0.002 \\
(0.20)\end{array}$ & $\begin{array}{l}0.008 \\
(0.57)\end{array}$ & $\begin{array}{l}0.009 \\
(0.72)\end{array}$ & $\begin{array}{l}-0.039^{* *} \\
(3.17)\end{array}$ & $\begin{array}{l}-0.005 \\
(0.32)\end{array}$ & $\begin{array}{l}-0.005 \\
(1.07)\end{array}$ & $\begin{array}{l}-0.004 \\
(0.70)\end{array}$ \\
\hline working & $\begin{array}{l}0.058^{* *} \\
(3.42)\end{array}$ & $\begin{array}{l}0.057^{* *} \\
(4.77)\end{array}$ & $\begin{array}{l}0.074^{* *} \\
(7.50)\end{array}$ & $\begin{array}{l}0.061^{* *} \\
(5.68)\end{array}$ & $\begin{array}{l}0.066^{* *} \\
(4.34)\end{array}$ & $\begin{array}{l}0.037^{* *} \\
(2.73)\end{array}$ & $\begin{array}{l}0.030 \\
(1.70)\end{array}$ & $\begin{array}{l}0.077^{* *} \\
(5.54)\end{array}$ & $\begin{array}{l}0.025 \\
(1.55)\end{array}$ & $\begin{array}{l}0.044^{* *} \\
(2.80)\end{array}$ & $\begin{array}{l}0.068^{* *} \\
(18.32)\end{array}$ & $\begin{array}{l}0.104^{* *} \\
(18.89)\end{array}$ \\
\hline foreign born & $\begin{array}{l}0.027 \\
(1.76)\end{array}$ & $\begin{array}{l}-0.008 \\
(0.92)\end{array}$ & $\begin{array}{l}-0.021 \\
(1.83)\end{array}$ & $\begin{array}{l}-0.002 \\
(0.14)\end{array}$ & $\begin{array}{l}0.039 \\
(1.31)\end{array}$ & $\begin{array}{l}0.056 \\
(1.87)\end{array}$ & $\begin{array}{l}-0.000 \\
(0.03)\end{array}$ & $\begin{array}{l}-0.038 \\
(1.61)\end{array}$ & $\begin{array}{l}-0.010 \\
(0.30)\end{array}$ & $\begin{array}{l}-0.028 \\
(1.91)\end{array}$ & $\begin{array}{l}0.049^{* *} \\
(8.21)\end{array}$ & $\begin{array}{l}-0.008 \\
(1.18)\end{array}$ \\
\hline fem current smoker & $\begin{array}{l}-0.007 \\
(0.41)\end{array}$ & $\begin{array}{l}-0.006 \\
(0.37)\end{array}$ & $\begin{array}{l}-0.013 \\
(1.04)\end{array}$ & $\begin{array}{l}-0.002 \\
(0.16)\end{array}$ & $\begin{array}{l}0.018 \\
(0.64)\end{array}$ & $\begin{array}{l}0.031 \\
(1.90)\end{array}$ & $\begin{array}{l}0.010 \\
(0.41)\end{array}$ & $\begin{array}{l}-0.002 \\
(0.11)\end{array}$ & $\begin{array}{l}0.020 \\
(0.99)\end{array}$ & $\begin{array}{l}-0.027 \\
(1.29)\end{array}$ & $\begin{array}{l}-0.016^{*} \\
(2.32)\end{array}$ & $\begin{array}{l}-0.020^{* *} \\
(2.79)\end{array}$ \\
\hline fem former smoker & $\begin{array}{l}-0.000 \\
(0.01)\end{array}$ & $\begin{array}{l}-0.001 \\
(0.06)\end{array}$ & $\begin{array}{l}-0.007 \\
(0.73)\end{array}$ & $\begin{array}{l}-0.013 \\
(1.26)\end{array}$ & $\begin{array}{l}-0.021 \\
(0.78)\end{array}$ & $\begin{array}{l}0.007 \\
(0.46)\end{array}$ & $\begin{array}{l}-0.025 \\
(1.22)\end{array}$ & $\begin{array}{l}-0.031^{*} \\
(2.14)\end{array}$ & $\begin{array}{l}-0.053^{*} \\
(2.08)\end{array}$ & $\begin{array}{l}-0.016 \\
(0.76)\end{array}$ & $\begin{array}{l}-0.034^{\star *} \\
(7.33)\end{array}$ & $\begin{array}{l}-0.029^{* *} \\
(5.40)\end{array}$ \\
\hline male current smoker & $\begin{array}{l}-0.013 \\
(0.77)\end{array}$ & $\begin{array}{l}0.032^{*} \\
(2.26)\end{array}$ & $\begin{array}{l}-0.017 \\
(1.18)\end{array}$ & $\begin{array}{l}0.009 \\
(0.62)\end{array}$ & $\begin{array}{l}-0.024 \\
(1.42)\end{array}$ & $\begin{array}{l}-0.020 \\
(1.26)\end{array}$ & $\begin{array}{l}-0.016 \\
(0.70)\end{array}$ & $\begin{array}{l}-0.026 \\
(1.41)\end{array}$ & $\begin{array}{l}0.025 \\
(1.46)\end{array}$ & $\begin{array}{l}-0.023 \\
(1.12)\end{array}$ & $\begin{array}{l}0.002 \\
(0.25)\end{array}$ & $\begin{array}{l}-0.031^{* *} \\
(3.61)\end{array}$ \\
\hline male former smoker & $\begin{array}{l}-0.061^{* *} \\
(4.00)\end{array}$ & $\begin{array}{l}-0.008 \\
(0.73)\end{array}$ & $\begin{array}{l}-0.022^{*} \\
(2.28)\end{array}$ & $\begin{array}{l}-0.015 \\
(1.20)\end{array}$ & $\begin{array}{l}-0.067^{\star *} \\
(4.64)\end{array}$ & $\begin{array}{l}-0.070^{\star *} \\
(5.35)\end{array}$ & $\begin{array}{l}0.002 \\
(0.10)\end{array}$ & $\begin{array}{l}-0.036^{*} \\
(2.10)\end{array}$ & $\begin{array}{l}-0.026 \\
(1.60)\end{array}$ & $\begin{array}{l}-0.046^{*} \\
(2.58)\end{array}$ & $\begin{array}{l}-0.027^{\star *} \\
(5.15)\end{array}$ & $\begin{array}{l}-0.044^{\star *} \\
(6.90)\end{array}$ \\
\hline Constant & $\begin{array}{l}0.834^{* *} \\
(18.88)\end{array}$ & $\begin{array}{l}0.717^{* *} \\
(17.61)\end{array}$ & $\begin{array}{l}0.782^{* *} \\
(16.85)\end{array}$ & $\begin{array}{l}0.774^{* *} \\
(22.88)\end{array}$ & $\begin{array}{l}0.828^{* *} \\
(20.79)\end{array}$ & $\begin{array}{l}0.838^{* *} \\
(21.70)\end{array}$ & $\begin{array}{l}0.689^{* *} \\
(12.55)\end{array}$ & $\begin{array}{l}0.881^{* *} \\
(16.33)\end{array}$ & $\begin{array}{l}0.765^{\star *} \\
(13.55)\end{array}$ & $\begin{array}{l}0.955^{\star *} \\
(16.44)\end{array}$ & $\begin{array}{l}0.475^{\star *} \\
(23.80)\end{array}$ & $\begin{array}{l}0.764^{* *} \\
(44.43)\end{array}$ \\
\hline Observations & 1601 & 2268 & 2458 & 2220 & 1906 & 2107 & 1272 & 1254 & 1491 & 717 & 10744 & 9291 \\
\hline R-squared & 0.16 & 0.22 & 0.27 & 0.22 & 0.25 & 0.19 & 0.26 & 0.23 & 0.29 & 0.17 & 0.21 & 0.17 \\
\hline
\end{tabular}

Absolute value of t statistics in parentheses; * significant at $5 \%$; ${ }^{* *}$ significant at $1 \%$ 
Table A2: Education related inequalities in health and health covariates (concentration indices)

\begin{tabular}{|c|c|c|c|c|c|c|c|c|c|c|c|c|}
\hline & AT & $\mathrm{DE}$ & SE & $\mathrm{NL}$ & ES & IT & FR & DK & GR & $\mathrm{CH}$ & US & UK \\
\hline health & 0.021 & 0.025 & 0.026 & 0.022 & 0.032 & 0.033 & 0.035 & 0.025 & 0.036 & 0.017 & 0.028 & 0.032 \\
\hline isced2 & & & -0.561 & -0.789 & -0.276 & -0.414 & -0.487 & & -0.380 & -0.760 & -0.961 & -0.711 \\
\hline isced3/4 & -0.666 & -0.777 & 0.033 & -0.171 & 0.601 & 0.346 & 0.110 & -0.718 & 0.344 & -0.213 & -0.789 & -0.097 \\
\hline isced5/6 & 0.148 & -0.006 & 0.413 & 0.444 & 0.810 & 0.693 & 0.442 & -0.011 & 0.617 & 0.307 & -0.069 & 0.523 \\
\hline men $60-64$ & 0.237 & 0.224 & 0.096 & 0.125 & 0.180 & 0.186 & 0.075 & 0.139 & 0.255 & 0.166 & 0.077 & 0.306 \\
\hline men 65-69 & 0.113 & 0.158 & -0.067 & 0.009 & -0.023 & 0.131 & 0.042 & 0.130 & 0.101 & 0.087 & 0.026 & 0.165 \\
\hline men $70-74$ & 0.112 & 0.109 & -0.081 & 0.011 & -0.070 & -0.062 & 0.018 & 0.078 & -0.021 & 0.120 & -0.011 & -0.272 \\
\hline men $75-79$ & 0.089 & 0.116 & -0.167 & 0.030 & -0.061 & 0.083 & -0.135 & 0.077 & -0.168 & -0.001 & -0.067 & -0.274 \\
\hline men $80+$ & 0.011 & 0.119 & -0.132 & 0.031 & -0.120 & -0.200 & -0.015 & 0.012 & -0.208 & -0.081 & -0.087 & -0.311 \\
\hline women 55-59 & 0.012 & 0.114 & 0.290 & 0.119 & 0.200 & 0.094 & 0.152 & 0.141 & 0.227 & 0.137 & 0.052 & 0.248 \\
\hline women $60-64$ & -0.040 & -0.023 & 0.161 & -0.001 & 0.039 & 0.063 & 0.069 & 0.016 & -0.008 & 0.012 & -0.056 & 0.179 \\
\hline women $65-69$ & -0.131 & -0.086 & 0.044 & -0.091 & -0.052 & 0.004 & -0.052 & -0.115 & -0.117 & -0.151 & -0.038 & 0.068 \\
\hline women $70-74$ & -0.118 & -0.302 & -0.056 & -0.213 & -0.130 & -0.196 & -0.120 & -0.144 & -0.205 & -0.125 & -0.052 & -0.300 \\
\hline women $75-79$ & -0.258 & -0.294 & -0.231 & -0.224 & -0.190 & -0.122 & -0.194 & -0.251 & -0.265 & -0.272 & -0.123 & -0.301 \\
\hline women $80+$ & -0.278 & -0.364 & -0.293 & -0.263 & -0.165 & -0.351 & -0.261 & -0.398 & -0.287 & -0.252 & -0.160 & -0.345 \\
\hline income & 0.008 & 0.013 & 0.011 & 0.015 & 0.007 & 0.011 & 0.011 & 0.012 & 0.012 & 0.012 & 0.020 & 0.024 \\
\hline wealth & 0.024 & 0.035 & 0.016 & 0.042 & -0.000 & 0.040 & 0.030 & 0.036 & 0.017 & 0.020 & 0.045 & 0.045 \\
\hline divorced & 0.130 & 0.180 & 0.047 & -0.031 & 0.284 & 0.440 & 0.176 & -0.005 & 0.245 & 0.012 & -0.019 & 0.102 \\
\hline single & 0.122 & 0.218 & 0.047 & -0.036 & 0.431 & 0.327 & 0.231 & -0.017 & 0.318 & -0.045 & 0.082 & 0.022 \\
\hline widowed & -0.206 & -0.232 & -0.186 & -0.189 & -0.123 & -0.153 & -0.216 & -0.224 & -0.173 & -0.208 & -0.154 & -0.267 \\
\hline working & 0.339 & 0.268 & 0.243 & 0.296 & 0.310 & 0.424 & 0.263 & 0.234 & 0.334 & 0.147 & 0.109 & 0.295 \\
\hline foreign born & 0.006 & -0.024 & 0.120 & -0.017 & 0.358 & 0.114 & -0.063 & 0.181 & 0.037 & -0.045 & -0.142 & 0.053 \\
\hline fem current smoker & 0.037 & -0.048 & -0.015 & -0.125 & 0.282 & 0.095 & 0.194 & -0.176 & 0.115 & -0.021 & -0.171 & -0.088 \\
\hline fem former smoker & -0.032 & 0.050 & 0.103 & -0.002 & 0.276 & 0.119 & 0.210 & -0.053 & 0.167 & -0.067 & -0.006 & -0.051 \\
\hline male current smoker & 0.143 & 0.142 & -0.130 & 0.003 & 0.158 & 0.100 & 0.230 & 0.113 & 0.166 & 0.170 & -0.082 & 0.016 \\
\hline male former smoker & 0.186 & 0.215 & -0.010 & 0.113 & -0.023 & 0.109 & 0.046 & 0.084 & 0.062 & 0.078 & 0.022 & 0.043 \\
\hline
\end{tabular}



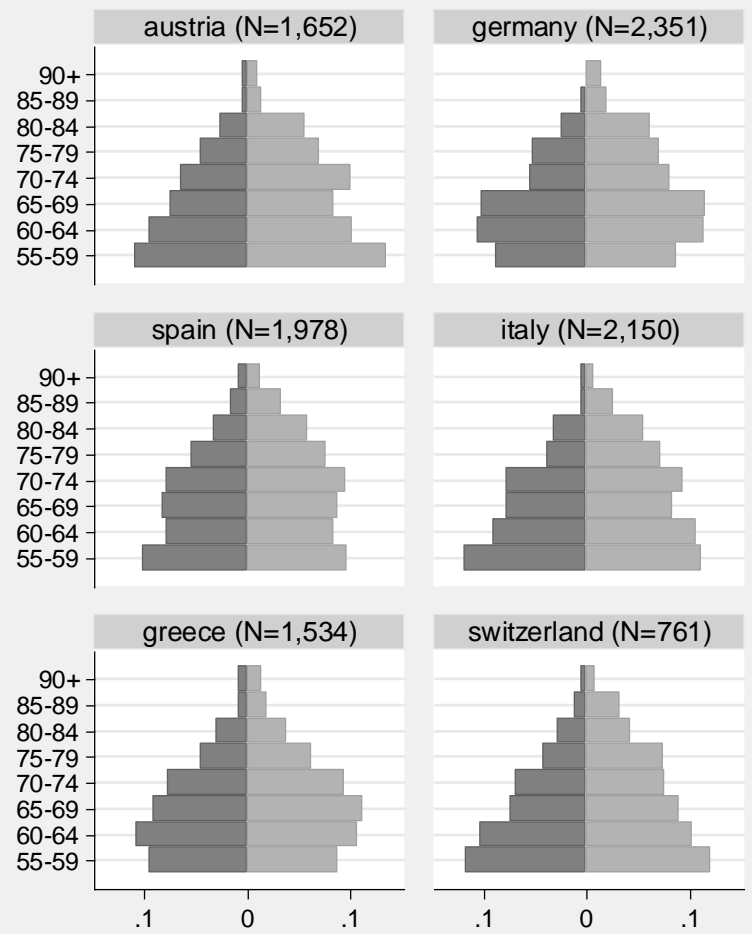

italy $(\mathrm{N}=2,150)$
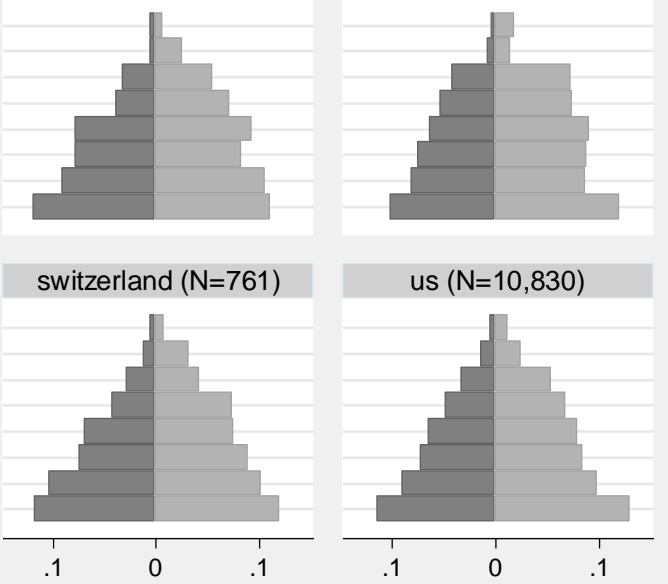

Proportion

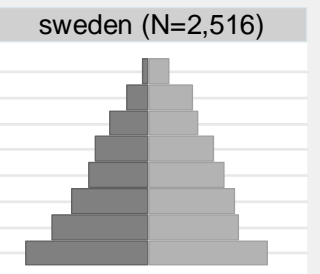

france $(\mathrm{N}=1,360)$

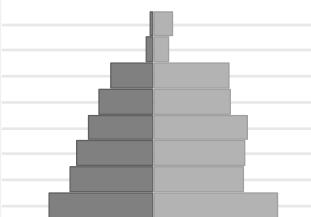

$(\mathrm{N}=10,830)$

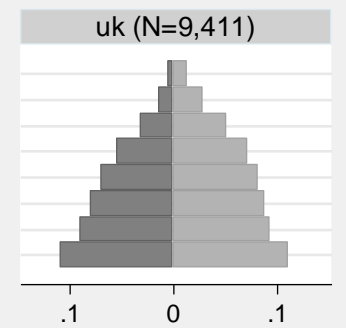
Men Women

Figure 1: Sample sizes, age and sex distribution, by country 


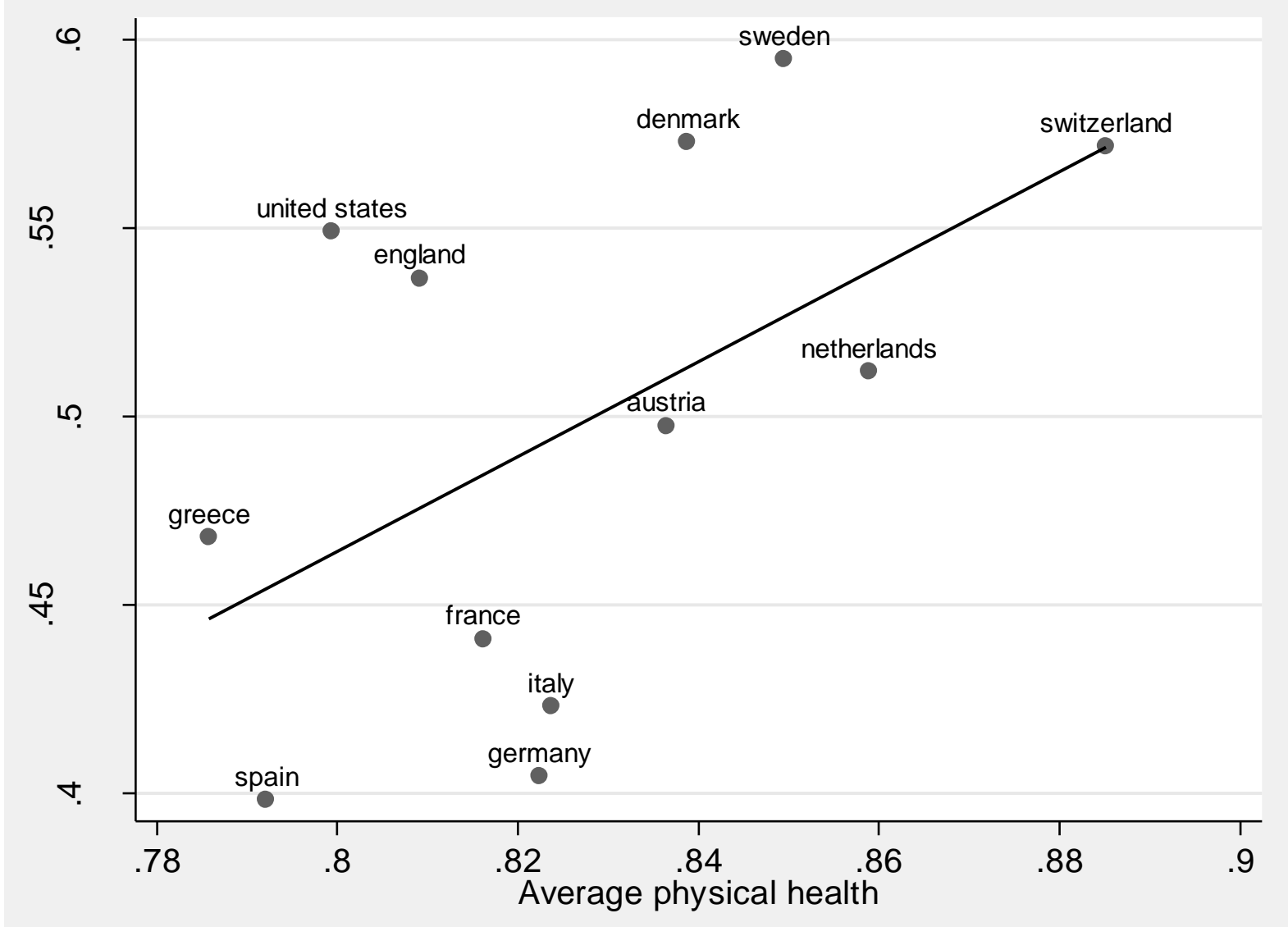

Figure 2: Average self-rated health and average physical health index, by country 


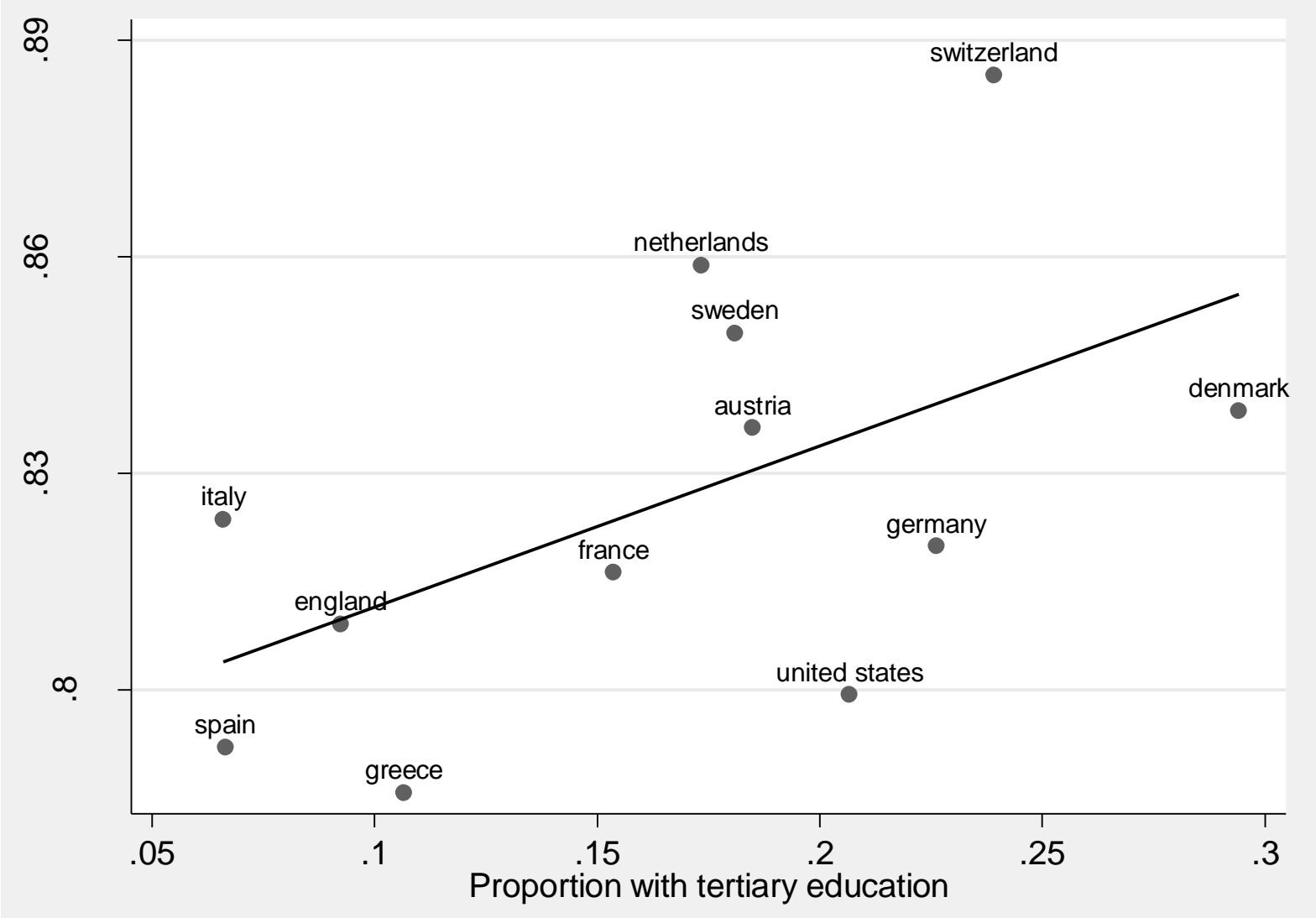

Figure 3. Cross-national correlation between education and health 


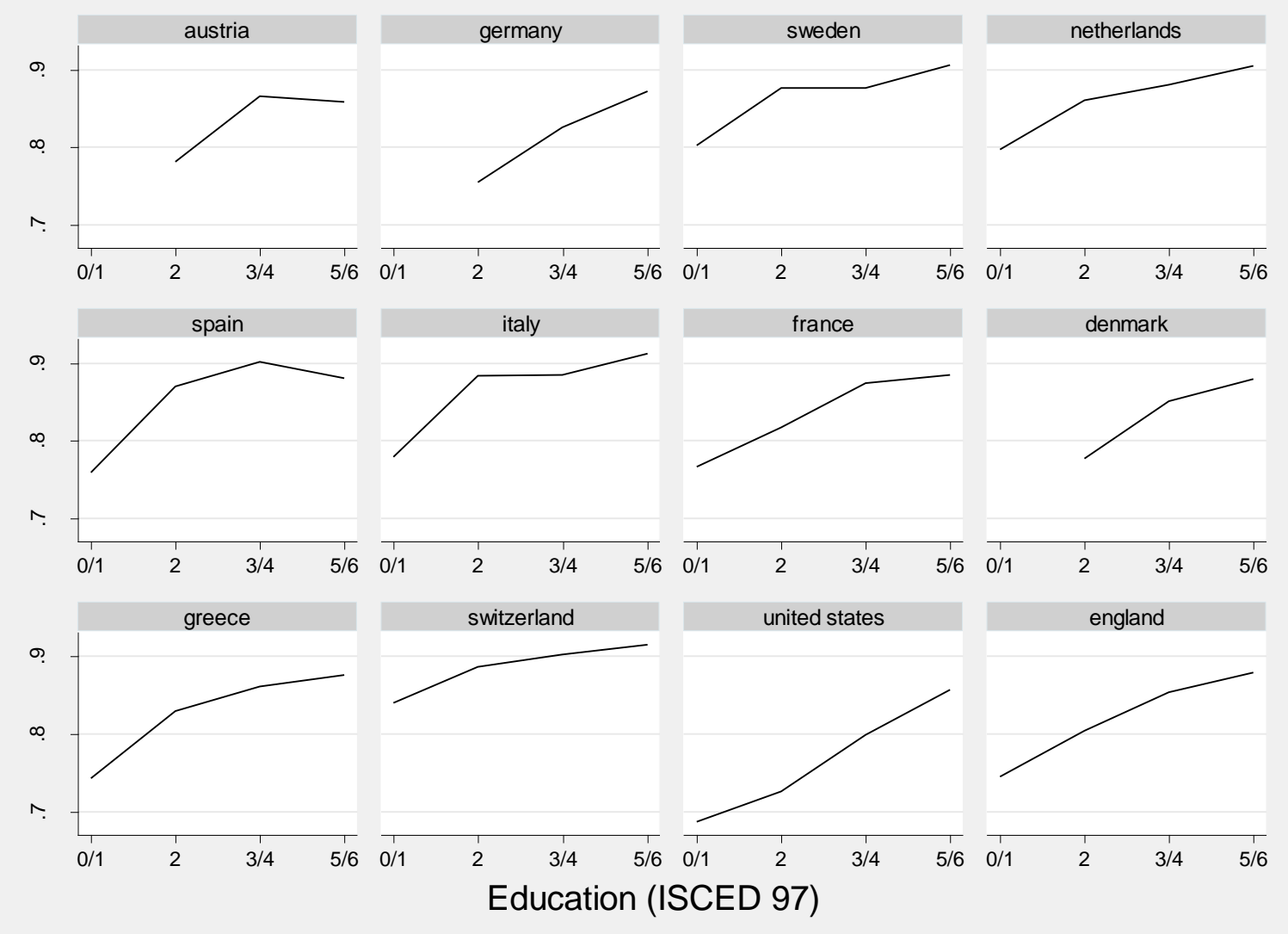

Figure 4: Physical health, by education level and country 


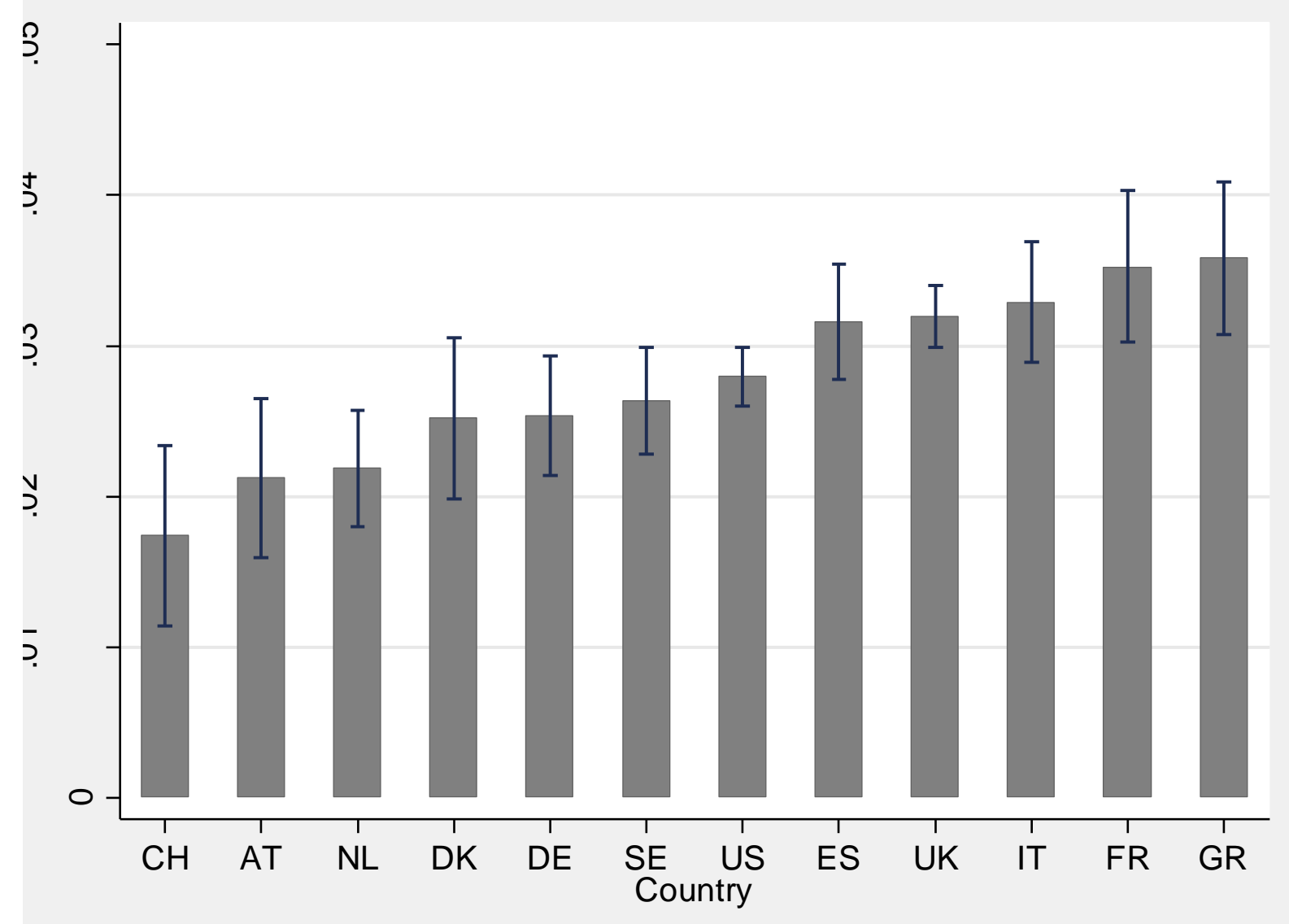

Figure 5: Health concentration index by country, with $90 \%$ confidence interval $(\mathrm{CH}=$ Switzerland, AT=Austria, $\mathrm{NL}=$ Netherlands, $\mathrm{DK}=$ Denmark, $\mathrm{DE}=$ Germany, $\mathrm{SE}=$ Sweden, US=United States, ES=Spain, UK=England, IT=Italy, FR=France, GR=Greece) 


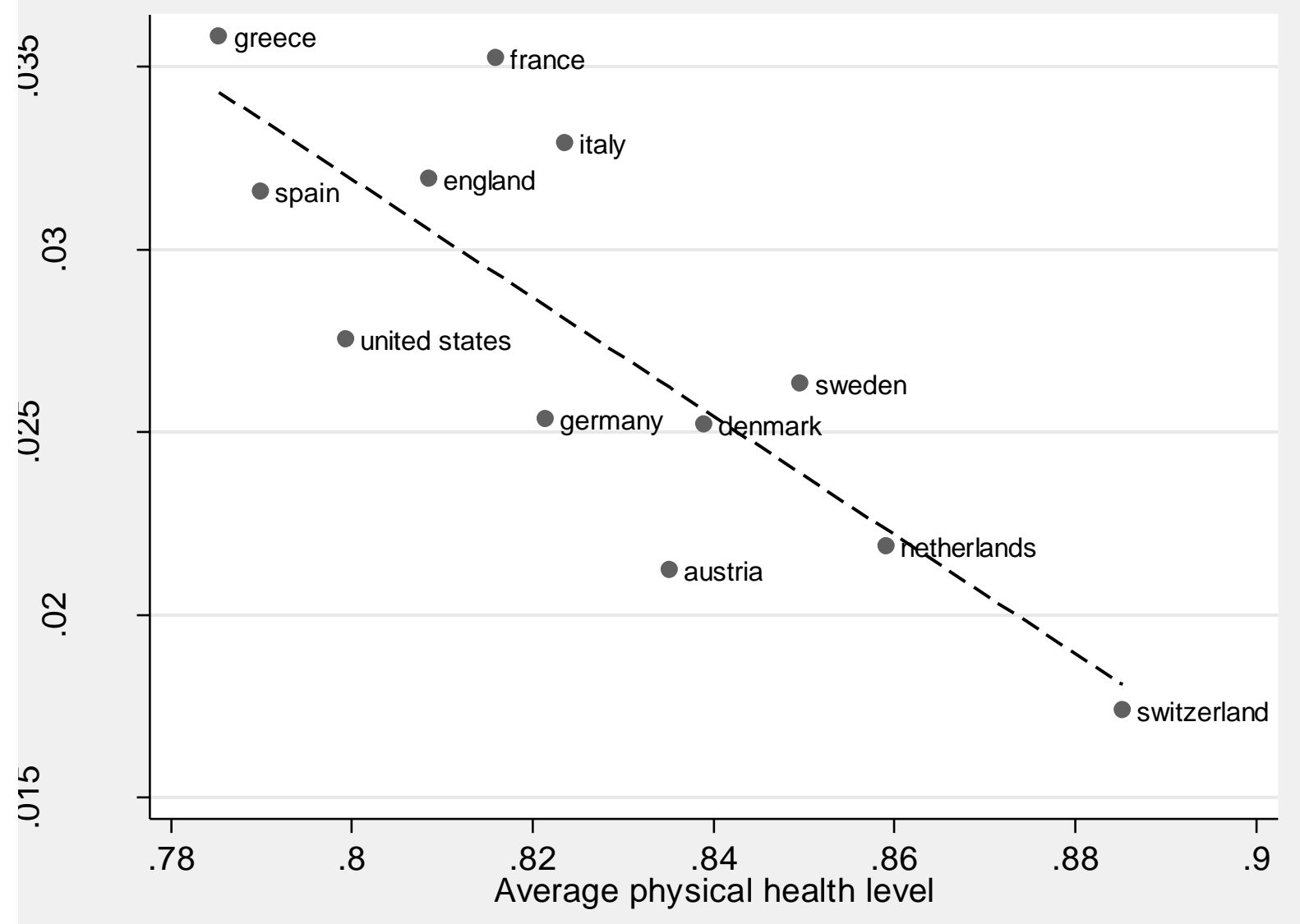

Figure 6: No trade-off between average health and health inequality 


\section{Discussion Paper Series}

Mannheim Research Institute for the Economics of Aging Universität Mannheim

To order copies, please direct your request to the author of the title in question.

\begin{tabular}{|c|c|c|c|}
\hline Nr. & Autoren & Titel & Jahr \\
\hline $129-07$ & $\begin{array}{l}\text { Axel Börsch-Supan } \\
\text { Alexander Ludwig } \\
\text { Mathias Sommer }\end{array}$ & Aging and Asset Prices & 07 \\
\hline $130-07$ & Axel Börsch-Supan & $\begin{array}{l}\text { Nachfrageseitiger Wettbewerb im } \\
\text { Gesundheitswesen }\end{array}$ & 07 \\
\hline $131-07$ & $\begin{array}{l}\text { Florian Heiss, Axel } \\
\text { Börsch-Supan, Michael } \\
\text { Hurd, David Wise }\end{array}$ & $\begin{array}{l}\text { Pathways to Disability: Predicting Health } \\
\text { Trajectories }\end{array}$ & 07 \\
\hline $132-07$ & Axel Börsch-Supan & Rational Pension Reform & 07 \\
\hline $133-07$ & Axel Börsch-Supan & Über selbststabilisierende Rentensysteme & 07 \\
\hline $134-07$ & $\begin{array}{l}\text { Axel Börsch-Supan, } \\
\text { Hendrik Jürges }\end{array}$ & $\begin{array}{l}\text { Early Retirement, Social Security and Well- } \\
\text { Being in Germany }\end{array}$ & 07 \\
\hline $135-07$ & Axel Börsch-Supan & Work Disability, Health, and Incentive Effects & 07 \\
\hline $136-07$ & $\begin{array}{l}\text { Axel Börsch-Supan, } \\
\text { Anette Reil-Held, } \\
\text { Daniel Schunk }\end{array}$ & $\begin{array}{l}\text { The savings behaviour of German households: } \\
\text { First Experiences with state promoted private } \\
\text { pensions }\end{array}$ & 07 \\
\hline $137-07$ & $\begin{array}{l}\text { Hendrik Jürges, } \\
\text { Mauricio Avendano, } \\
\text { Johan Mackenbach }\end{array}$ & $\begin{array}{l}\text { How comparable are different measures of self- } \\
\text { rated health? Evidence from five European } \\
\text { countries }\end{array}$ & 07 \\
\hline $138-07$ & $\begin{array}{l}\text { Hendrik Jürges, } \\
\text { Kerstion Schneider }\end{array}$ & $\begin{array}{l}\text { What can go wrong will go wrong: Birthday } \\
\text { effects and early tracking in the German school } \\
\text { system }\end{array}$ & 07 \\
\hline $139-07$ & Hendrik Jürges & $\begin{array}{l}\text { Does ill health affect savings intentions? } \\
\text { Evidence from SHARE }\end{array}$ & 07 \\
\hline $140-07$ & Hendrik Jürges & $\begin{array}{l}\text { Health inequalities by education, income, and } \\
\text { wealth: a comparison of } 11 \text { European countries } \\
\text { and the US }\end{array}$ & 07 \\
\hline $141-07$ & Hendrik Jürges & $\begin{array}{l}\text { Healthy minds in healthy bodies. An } \\
\text { international comparison of education-related } \\
\text { inequality in physical health among older adults }\end{array}$ & 07 \\
\hline
\end{tabular}

